\title{
PERSPECTIVES FOR ECONOMIC VIABILITY AND SUSTAINABLE DEVELOPMENT OF BULGARIAN AGRICULTURE IN THE NEW PROGRAMMING PERIOD 2014 - 2020
}

\author{
D. Atanasov* \\ Economics Department, Agricultural University - Plovdiv, Bulgaria
}

\begin{abstract}
European agriculture is influenced by many factors. Natural resources are limited, economic conditions and market environment are dynamic, consumer requirements change, as well as the climate. This determines the state and the trends in agriculture and in the economy of any country. In Bulgaria these influences are sensed stronger, because of the superimposition of internal problems, such as political instability, economic and social uncertainty, underdeveloped infrastructure, dysfunctional institutions. The framework in which agriculture operates is constantly modifying to make its adaptation to the changes easier and smoother. The Common agricultural policy (CAP) and the rural development program (RDP) during 2007 - 2013 contributed to agriculture's development in Bulgaria, but also had serious weaknesses, causing negative impacts on certain sectors and farm types. For the period $2014-2020$, the CAP and the RDP have many improvements and better philosophy, aimed at providing conditions for smart and sustainable growth.

The purpose of this research is presenting and analyzing some of the important changes in the European Union's agricultural policy and Bulgaria's rural development program to overcome the problems from the previous planning period and provide prerequisites for viability and sustainability of farming systems in the country.
\end{abstract}

Key words: economic viability, sustainability, policy.

\section{INTRODUCTION}

In the scientific literature a wide variety of terms are used as synonyms of viability resilience, flexibility, elasticity, robustness, toughness etc. In general viability is described as ability of a system to recover from shocks, to survive and to preserve its integrity, which applies to both ecological and social systems.

Researchers outline two attributes of the system affecting its viability. One is the capacity to adapt to changes (Carpenter et al, 2001, Bengtsson et al, 2003) and second is the robustness to absorb external shocks without allowing them to cause serious disruption (Webb and Levin, 2005). Viable systems have capacity to absorb shocks without losing functionality. In economic systems it is associated with their ability to withstand market or environmental changes and not compromising the rational exploitation of

\footnotetext{
*Correspondence to: Dimo Atanasov, Economics department, Agricultural University - Plovdiv, 12 "Mendeleev" str., 4000 Plovdiv, Bulgaria, 032/654 382, 0885/843553, e-mail:
} atanasov.phd@gmail.com inputs and the supply of products and services to the end users (1). Understanding the dynamics of a system is important for its sustainability because it allows decisionmakers to choose whether to adapt to future influences and impacts or to take action to mitigate them and prevent changes. The capacity of the ecological-economic system to function in a range of social and environmental conditions, depends on the combination of assets that haven't only financial and material value, but also natural (1).

It is complicated to define what makes farming systems flexible and viable, but here again it could be pointed out their potential to overcome stressful situations (droughts, floods, hail storms, market and institutional instability etc.) and continue development in the desired direction. The influential factors could be divided to: natural-climatic (soil, climate, topography, altitude, rainfall, temperature, environmental condition, biodiversity) and socio-economic (investment, consumption, demographic resources, state of the processing industry, state of the transport infrastructure, social protection, scientific discoveries, 
ATANASOV D.

technologies, institutional frameworks etc.). More dynamic in recent years, however are the factors in the second group. The peculiarities of agricultural production systems predetermine their great vulnerability to the dynamics of the external environment. That's why it is necessary to observe the main external factors and analyze the opportunities and dangers created by them. A similar opinion have Hadjieva et al (2005), according to which if the farmer is capable to analyze external influences, he/she could consciously orient activities in one or other direction in order to optimize the results and minimize the possible negative consequences (2).

External factors are many, but can be grouped in the following aspects:

- Natural and climatic factors. The majority of Bulgaria's territory has favorable natural and climatic resources for development of modern agriculture. The direction to follow in the future is adaptation to climate change through best practices, new technologies, more resistant varieties and breeds, as well as minimizing the negative environmental impact from agriculture.

- Ecological factors, together with the climate are related to the potential of a region to provide the necessary resource base for development of agriculture, including crop and animal production, as well as other economic activities such as tourism, forestry, herbs collection etc. When pursuing sustainable development of a production system, environmental factors are a mandatory requirement and should be included in the equation. The main environmental conditions that must be respected by farmers are related to soils, water, ecosystems health, biodiversity, etc.

- Economic factors. The macro environment is not favorable to agriculture at this stage. Difficult and relatively expensive lending of money is a serious problem for normal functioning of farms. Many financial institutions do not grant loans to farmers. Moreover annual interest rate of about $10 \%$ is too high for the low efficient farming business. Taxation that was introduced in 2010 is another burden that reduces the profitability of farms. The subsidies as an element of the macroeconomic environment are not equally effective for all types of farms. The Single Area Payment Scheme (SAPS) doesn't favor smaller and intensive production systems, especially in the animal breeding. Only since 2010 new schemes for livestock support have been introduced, taking into account the number of animals. The import regimes are also not protecting the national agricultural producers. Often low quality but cheap products are allowed to enter Bulgarian market, which is not good to farmers neither to consumers.

- Social factors. They reflect the relations in society and attitudes of different social groups to the farming activities. It is important to highlight the trends in recent years towards shifting the people's interest to a more rational eating habits and consumption of healthier food, as well as concerns about food quality and animal welfare. Providing employment and income, as social benefits from farming also show positive trends, especially in large production units. With the adaptation to CAP the safety of workplace and good working conditions are also getting better. Farmers and their families should also receive certain social benefits for doing business. Their integration into society is very important, their living standard and access to various social services such as schools, kindergartens, hospitals, restaurants, cinemas and more are important too. In some regions farming communities have access to some or most of these services, but in others don't.

- Institutional (political) factors. The complex of policies in a given sector of agriculture influences the behavior of farmers and limits their development in a certain frame. The level of viability and sustainability of a farm depends on the existence of public support programs, social protection mechanisms, quality standards, requirements for the working conditions, animal welfare, environmental protection and others. The main political factors are related to the provision of incentives and regulation of production, maintaining stable prices, direct support and help through the rural development program. Furthermore, cross compliance impose to farms certain standards for environmental protection, production of quality food as well as application of good agricultural practices and practices complying to the animal welfare requirements. Bulgaria, as a member of the EU is obliged to ensure that the products offered on the market and those intended for export comply with the relevant requirements.

On a global scale significant changes in the political, economic and social conditions are taking place, affecting farming and people involved in this business. The main challenges to the future development of agriculture are:

- Rapid integration and globalization of food chains, which offer opportunities to some farming systems, but make market access more difficult for small ones, because of the high transaction costs and high requirements for production and supply of products; 
- Competition on the world market and the low prices of agricultural products could force farmers to abandon agriculture and their production be replaced by cheap imports;

- Small family farms have to compete with large and technologically developed companies, that through economies of scale and better marketing have advantages;

- Climate change increases the risk of agriculture, which is most difficult to bear by small farms and often they quit business.

As a result of these circumstances, a large number of farmers are becoming increasingly dependent on external support and programs for their survival, a situation that can prove neither socially nor financially sustainable. Now is the time to review some traditional approaches to help farms. Serious work needs to be done in order to provide new opportunities for establishing and developing of viable production systems in the agricultural sector. The vision should be pointed at specific and expensive Bulgarian products and activities with high added value. It is also important to promote opportunities for nonfarm employment in rural areas, to diversify farmers income. The urgency of solving these problems is prompted by the growing commitment of government policies with investment in sustainable agriculture.

In the new programming period the rural development program has the following main objectives (3):

1. Improving competitiveness and achieving balanced development of agriculture, forestry and processing industry;

2. Preservation of ecosystems and sustainable management of natural resources in agriculture, forestry and food industry, as well as climate change prevention and adaptation;

3. Socio-economic development of rural areas, providing new jobs, poverty reduction, social inclusion and better quality of life;

The first objective is providing sustainable and balanced growth of production and processing of agricultural and forestry products, as envisaged measures are aimed at: restructuring of the agricultural sector to enhance sustainability of farms, promoting quality production, value addition, production and marketing innovation, improving the economic performance of companies in the forestry and sustainable forest management (3).

The program prioritizes the improvement of competitiveness and viability of agricultural and forestry systems by modernization and technological innovation, attracting young people into the sector with appropriate qualifications, training and consultancy,
ATANASOV D.

encouraging investment and increasing productivity, energy and resource efficiency and sustainability. Most attention will be paid to the sectors: meat and milk, fruits and vegetables, essential oils and organic production and it will be given priority to projects developed in these sectors. Another priority is to improve the organization of the food chain and risk management by promoting cooperation aimed at building a competitive advantages, based on quality and value added products and innovations. It will be important to achieve vertical and horizontal integration in agriculture and the food chain. The risk in agriculture will be minimized by supporting the creation of a mutual fund from 2017 to adverse weather conditions, animal diseases and plant pests or environmental accidents (3).

In order to help the development of small farms a thematic sub-program is addressed, which seeks to facilitate their restructuring, increase viability and sustainability. The program will support the provision of advisory services, investments and activities aimed at increasing the production scale, structural adjustment, increasing productivity and quality of output of small farms and thus increase their income and preserve jobs. The thematic sub-program aims to improve the resource allocation and to reduce the administrative burden, to stimulate development of specialized services for small farms, but also to raise public awareness and commitment to ensure their sustainable development (3).

The second objective of the program is aimed at preserving ecosystems, ensuring sustainable management and use of natural resources, preventing and also adapting to climate change. Within this purpose are programmed interventions in two priorities. One relates to the conservation of biodiversity and natural resources. EU strategy for biodiversity by 2020 , aims the suspension of its loss and degradation of ecosystem services. It focuses on the conservation of habitats and species in agricultural and forest areas, including "Natura 2000 " and the conservation of genetic diversity in agriculture. The reduction of water pollution from agriculture is also addressed by supporting investments in farms and equipment. Organic production will also be supported by the tools of European agricultural fund for rural development (EAFRD) because it has a positive impact in achieving the objectives of the European strategy for biodiversity conservation "Europe 2020", the Communication on Green Infrastructure, the Thematic Strategy on soil and European legislation - Birds and Habitats Directive, Nitrates Directive, Water Directive 
and others. The second priority seeks to promote efficient use of resources and support the transition to low carbon and climate change resilient economy. Under this priority, the program includes measures that address the objectives and priorities set by the Third National Action Plan on Climate Change 2013 2020 for agriculture, land use, forestry and industry.

In order to adapt to climate change investments in water-saving irrigation technologies and irrigation infrastructure will be encouraged. Funds will be provided for investments in energy efficiency, use of renewable resources and processing of by-products, wastes, residues and other materials in bio-energy. From the perspective of reducing greenhouse gas emissions the priority will be investments in storage of manure and sustainable practices for the processing of agricultural lands as the main sources of greenhouse gases from agriculture. In this regard the conservation and carbon sequestration by increasing the viability and sustainability of forests, reforestation and restoration of shelter belts and restore forests damaged by fires and disasters will be encouraged (3).

The third objective of the program is to stimulate the socio-economic development of rural areas. Within this objective interventions will be supported in three priority areas that together aim to develop economic potential, to preserve the demographic situation and contribute to social inclusion of vulnerable groups in society, thus contributing to economic recovery and curb demographic processes. One of the objectives is to facilitate the diversification of the economy and job creation in rural areas, by encouraging investment in the creation and development of non-agricultural business. The program will support investments in the development of non-agricultural activities, with priority to those utilizing internal resources of rural areas or opportunities presented by the development of new technologies (3).

The program is in line with the "Europe 2020" strategy for inclusive growth and by prioritizing the creation and preservation of jobs, it also promotes the development of labour-intensive agricultural sectors and help increase the viability of small farms. Attention is paid to improving the social and technical infrastructure, as well as the tourism infrastructure, by supporting investments, enhancing quality of life and access to services in rural areas. Other measures for recovery of the socio-economic potential of rural communities rely on local development under the LEADER approach. If necessary, direct help to local initiatives for capacity building and preparation of local development strategies will be provided. To enable local initiative groups (LIG) in their strategies to adequately address the most important issues of the territory, it is planed the implementation of complimentary multi-funding for the integration of interventions of regional and social policy and policies for rural development and maritime and fisheries (3).

Another way of making the financial support more equal to different farming systems is the introduction of multilayered structure of direct payments. The reform of the European Common Agricultural Policy requires changes in the direct payments methodology for the period 2015 - 2020. Bulgaria will implement the new major support schemes (3):

- Single Area Payment Scheme (SAPS). In order to ensure consistency in implementation of policy and take under consideration to the maximum extend the national specifics, SAPS in Bulgaria will be applied until 31 December 2020. In order the support to reach wider range of farms, the minimum size of production systems, entitled to subsidies have been reduced to 0,5 ha.

- Redistribution payments. More equitable targeting of the support will be achieved through the use of redistributing payment scheme. The budget of the scheme is within approximately $7 \%$ of the national ceiling for direct payments. Under this scheme, higher support is provided for the first 30 ha of agricultural land in all holdings;

- Support scheme for small farmers. In order to increase the competitiveness of small farms and ensure complementarity of income, a separate scheme aimed at these production units will be applied. The amount of annual payment, a farmer is entitled to, is determined by the amount of support that he/she would receive under the direct payment scheme, but not less than 500 euro. The support scheme for small farmers replaces all other schemes for direct support, but does not replace the payments under the Transitional national aid. Participation in the scheme can apply only for 2015 ;

- Support Scheme for young farmers. Encouraging the entry of young farmers in the agricultural sector is intended to be implemented through a separate scheme. Eligible to this support are people who began farming activities in the last five years and at the year of first application they are aged no more than 40 years. It is envisaged that the support for the first 30 ha of the farm is $25 \%$ higher than the SAPS. An important rrequirement for the young farmers, applicants for the scheme, is to 
have professional skills and knowledge, related to agriculture, which at the time of application must be certified.

- Ttransitional national aid. Applicable schemes for transitional national aid, starting from 2015 are transitional scheme for agricultural land, transitional national decoupled tobacco aid, transitional national decoupled aid for cattle, transitional national coupled aid for ewes and goats;

- Special payment for cotton. This payment is for farmers who grow cotton on the territory of Bulgaria, with a minimum density of 8000 plant/ha. and its variety belongs to the national or the EU crops catalog.

- Reduction of payments. In order to make the distribution of funds for direct payments between farmers more balanced, a reduction of the SAPS will apply, after deduction of expenses for salaries, insurance and taxes that are related to agricultural activity, actually paid and declared by the farmer. It will only be implemented for payments over 150000 Euro, which will be reduced by $5 \%$, and if the payment exceeds 300000 Euro, everything over that amount will be cut by $100 \%$.

- Active farmers. According to the requirements of Regulation (EC) 1307/2013, from 2015 onwards direct payments will be granted only to active farmers. The definition of active farmer, suggests that individuals and legal entities cannot receive payments if their agricultural areas are mainly (over 50\%) naturally kept in a state suitable for grazing or tillage and which do not carry minimum agricultural activities. Requirements for active farmer doesn,t apply to agricultural producers who have received less than 3000 Euro direct payments for the previous year.

- Green payments. One of the objectives of the new CAP is to improve the environmental performance of agricultural land by introducing a mandatory component "greening" of direct payments which will support agricultural practices beneficial for the climate and the environment. The contribution of agriculture in maintaining the ecological balance of the territory of Bulgaria will be done through the implementation of the so called "Green direct payments". The budget allocated for green payments, amounts to $30 \%$ of the ceiling on direct payments. Green payments will be implemented from 2015 campaign.

Farmers entitled to receive SAPS payments must comply in all of its hectares eligible for support, agricultural practices beneficial for the climate and the environment - diversification, maintaining permanent grassland and maintaining ecologically targeted areas.
- Diversification of crops - a requirement for growing several different crops on the farm in order to avoid monoculture production. It applies for farms with land more than 10 ha. Farms cultivating between 10 and 30 ha must keep at least two different crops, as the main one doesn't exceed $75 \%$ of the total arable area. Farms with arable land over 30 ha should have at least three crops. The main crop should not be more than $75 \%$ of the arable area. The two main crops should not occupy more than $95 \%$ of arable land.

- Maintenance of existing permanent grassland. Bulgaria has an obligation to define ecologically sensitive permanent grassland in the territories under Natura 2000 and to introduce a ban on plowing these areas by farmers. Agricultural producers should not transform and/or plow grassland, located in these areas. The state guarantees that the ratio of the permanent grassland to the total agricultural area declared by farmers does not decrease under $5 \%$.

- Ecologically focused areas. This applies from 2015 in farms with arable land exceeding 15 ha. At least $5 \%$ of the declared arable land should be occupied by ecologically focused areas. According to the national specifics, Bulgaria will apply the full list of ecologically focused areas, established in Regulation (EU) $1307 / 2013$, with the exception of traditional stone walls, forest farming systems and wooded areas. Ecologically focused areas are: land set aside; terraces; landscape features - hedges, trees, ponds, ditches, etc. (under certain conditions); buffer strips; strips of eligible hectares along the forest areas; trees with short rotation - (poplar, willow, black alder, silver linden, field elm, hazel, oriental plane and mulberry, introduced in the nomenclature of the name of the cultures and their codes for 2014 campaigning); areas with intermediate crops or green cover; Nitrogen-Fixing crops areas. The list of specific crops include: chickpeas, clover, beans, lentils, lupines, peas, vetch, sainfoin, trefoil, soybeans, bitter vetch, peanut, alfalfa, etc. (3).

There will be used schemes for coupled direct support too. The help for vulnerable and priority sectors will be carried out through the implementation of schemes for coupled support. The budget allocated for the coupled support, amounts to $13 \%$ of the ceiling for direct payments for sectors "Livestock" and "Fruits and vegetables" and $2 \%$ for protein crops. The notified schemes are as follows:

- Scheme for coupled support for dairy cows to assist farmers who keep 10 or more dairy cows, which are intended to produce milk in the Integrated Information System of Bulgarian Food Safety Agency; 
- Scheme for coupled support for meat cows/or heifers - to assist farmers who have 5 or more cows for meat and/or heifers, which are intended for meat production in the Integrated Information System of Bulgarian Food Safety Agency;

- Scheme for coupled support for dairy cows and/or meat cows under selection control - to support farmers who keep 10 or more dairy cows and/or meat cows, of which at least one animal is under selection control;

- Scheme for coupled support for ewes and goats - to assist farmers who breed from 10 to 49 ewes and/or goats;

- Scheme for coupled support for ewes and goats under selection control - to support farmers who have 50 or more ewes and/or goats, out of which at least one animal is under selection control;

- Scheme for coupled support for buffalos assists farmers who breed 10 or more buffaloes;

- Scheme for coupled support for fruits designed to support farmers throughout the country, that have at least 0,5 ha eligible areas of the following fruit crops: strawberries, raspberries, apples, pears, apricots, peaches and nectarines, plums, cherries, walnuts and table grapes;

- Scheme for coupled support for vegetables rights to this support have farmers throughout the country that have at least 0,5 ha of eligible land with the following vegetable crops: tomatoes, peppers, cucumbers, gherkins, cabbage, onions, eggplants, carrots, peas, green beans, garlic, potatoes, watermelons, melons and pumpkins;

- Scheme for coupled support for greenhouse vegetables - rights to this support have farmers throughout the country that have at least 0,5 ha of eligible land with greenhouses vegetable crops: tomato, pepper and cucumber;

- Scheme for coupled support for protein crops - meant for producers throughout the country who have at least 0,5 ha eligible areas of the following protein crops: beans, lentils, chickpeas, peas, peanuts, soy beans, alfalfa, sainfoin, vetch, clover, lupine and trefoil, etc.

As it can be seen, in the new programming period the CAP changes in order to meet the new realities in Europe. This affects its three dimensions of work: income support; market support; rural development;

\section{CONCLUSIONS}

Agricultural production systems are important from economical, ecological and social point of view to the sustainability and the overall development of regions and the whole economy. This analysis concludes that the economic and political realities imposed in Bulgaria during the last 25 years do not allow intensive agricultural systems to reach their production potential, despite the favorable resource base in the country. Direct support, as a key element of the European agricultural policy, through the single area payment scheme, creates advantages for farms with large utilized agricultural area (UAA). The funds from the rural development program 2007 - 2013, were mainly used by large farms, having administrative capacity to develop and manage investment projects, rather than small family farms, which most need it.

Bulgarian agriculture has rich natural and human resources, as well as traditions and scientific base, allowing sustainable development of current farms and opportunities for establishing and modernization of new ones. Technological development, creation and introduction of innovations should be used to the highest extend in order to improve the efficiency and competitiveness of production systems.

Viability and sustainable development farms can achieve by:

- Optimal use of economic, market and institutional conditions;

- Improving production potential, quality of production and distribution channels;

- Diversification of production structure and income sources;

- Use of local and regional comparative advantages;

- Horizontal and vertical integration;

- Minimizing the negative environmental effects, such as pollution of soil, water and air from the excessive use of fertilizers and pesticides, improper storage and use of waste, reduction of biodiversity by inappropriate production practices, the use of large amounts of water and electricity. It is necessary to improve the environmental compatibility of each production system through intelligent management, greater energy efficiency, conservation and enhancement of biodiversity in the region and implementation of environmentally friendly production practices.

- Strengthening the social aspect of the development and linking it to the interests of the region. When population is suffering inconvenience from the farming practices and at the same time is willing to transfer part of its income to support producers, it is entitled to receive some benefits from them, like employment, improved working conditions and salaries, high quality food etc.

The new agricultural policy of the EU and the new RDP for 2014 - 2020 have many improvements and different philosophy of 
administration, aimed at remedying the shortcomings of the previous programming period and providing better conditions for smart and sustainable growth. How this is going to work in Bulgaria is not yet clear, but many farmers hope and believe that the political and financial support will be more transparent, more efficient and more equitable.

The European sustainable development is not an option but a way, which we should take. The President of the European Commission - José Manuel Barroso, in a speech before the committee said that to ensure the sustainable future of Europe we should look ahead in the long run. Europe must re-enter the right path and stay there. Europe has the capacity to deliver smart, sustainable and inclusive growth, create new jobs and provide its citizens a sense of security and direction. For this purpose the strategy "Europe 2020" puts forward three mutually reinforcing priorities: smart growth (economy based on knowledge and innovation); sustainable growth (a resource efficient, greener and more competitive economy) and inclusive growth (promoting economic development, creating jobs, social and territorial cohesion) (4).
ATANASOV D.

When developing the strategy "Bulgaria 2020", politicians should harness all the knowledge and technology, intelligent foresight must be exercised and an exceptional sense of responsibility for the national interest in defining the guidelines for the development of important sectors like agriculture.

\section{REFERENCES}

1. Perrings, C., 2006 „Resilience and sustainable development", Environment and Development Economics 11: 417-427 C_2006 Cambridge University Press doi:10.1017/S1355770X06003020 Printed in the UK.

2. Hadjieva, V, D. Mitova, M. Atanasova, H. Bashev, V. Mitzov, S. Madjarova 2005 „Planning of Sustainable Development of the Agricultural farm", Economics and management of agriculture, 5/2005, p. 40;

3. Rural Development Program in Bulgaria for the period $2014-2020$;

4. European Commission, 2010 Communication from the commission "EUROPE 2020 A strategy for smart, sustainable and inclusive growth", $p .3$ 